\title{
Incidence of cancer among ferrochromium and ferrosilicon workers: an extended observation period
}

\author{
S Langård, A Andersen, J Ravnestad
}

\begin{abstract}
Results are presented of a cohort study on the incidence of cancers and crude death rates in ferrochromium and ferrosilicon workers. The whole cohort was observed from 1 January 1953 to 31 December 1985. Two sets of results are presented; one restricted to workers first employed before 1960 and one to workers first employed before 1965 . The latter cohort consists of 1235 workers. The total mortality in the whole cohort was low $(\mathrm{SMR}=81)$ as was the overall incidence of cancers $(S I R=84)$. There was an overall deficit of deaths and cases of cancer in the ferrosilicon group. An excess of lung cancer $(S I R=154)$ and cancer of the prostate $(\operatorname{SIR}=151)$ was observed in the ferrochromium workers employed before 1965 . Cancer of the kidney was also in excess $(S I R=273)$ in the ferrochromium group, with a mean "latency time" of 39 years. Two cases of malignant melanomas had occurred versus 0.19 expected in a small subgroup of workers in electrical shops and an electric power station.
\end{abstract}

For more than 50 years, hexavalent chromium compounds have been considered to constitute an occupational cancer hazard. ${ }^{12}$ Epidemiological studies have contributed much to the present knowledge of the carcinogenic effects of chromium ${ }^{\mathrm{IV}}$ compounds and to the knowledge of their carcinogenic potency. Nevertheless, as there are only a few reliable studies among well defined chromium exposed populations, ${ }^{3}$ there is still a need for supplementary results from such populations.

Some researchers have interpreted their results in favour of the view that exposure to trivalent chromium compounds may constitute a cancer hazard to exposed workers ${ }^{4}$ (and TF Mancuso at

\footnotetext{
Telemark Sentralsjukehus, Department of Occupational Medicine, N-3900 Porsgrunn, Norway $S$ Langård

Cancer Registry of Norway, Montebello, 0310 Oslo 3 A Andersen

Health Department, Bjolvefossen a/s, Ålvik

J Ravnestad
}

heavy metal conference, Toronto, 1975). These suggestions stimulated $\mathrm{us}^{5}$ and Axelsson et $a l^{6}$ to carry out studies in Norway and Sweden, respectively, to evaluate Mancuso's claims. As it was shown that the workers in these studies, at least to some extent, had been exposed to fumes containing chromium $^{\mathrm{IV}}$ compounds, the results derived from these two studies failed to evaluate the possible relation between exposure to chromium ${ }^{\mathrm{III}}$ and the development of bronchial cancer. The results from these two studies were not fully consistent; our study indicating an association between long term work at ferrochromium furnaces and occurrence of bronchial cancer, whereas no such association was indicated by the Swedish results.

The results generated in these studies have attracted interest among both regulatory and advisory agencies $^{378}$ and have been applied as a source of information in assessing the risk of cancer related to exposure to chromium in environmental air. ${ }^{9}$ To our knowledge, no studies of the incidence of cancer or cancer mortality in ferrochromium workers have been published since the above results were reported.

On these grounds we find it appropriate to reassess the results from the Norwegian ferrochromium study cohort by extending the observation period by a further eight years. The aim of the present extended study was to evaluate further whether the suggested association between exposure to fumes among ferrochromium workers and occurrence of lung cancer has strengthened or weakened, and further to explore the possibility that work related exposure in the study cohort may constitute a cancer hazard at sites other than the bronchial tree.

\section{Study plant and production}

The study plant and production were described in the previous report. ${ }^{5}$ In brief, the plant is located on the west coast of Norway in the county of Hordaland and has been operating since 1928. Production of ferrosilicon started in 1928 and ferrochromium in 1934. Ferrochromium production was terminated by the end of 1982 and no chromium production has taken place since. Several changes have taken place in the production methods during the observation period but the processing has mainly been based on electrochemical reduction of chromite ore and quartz with coke. From 1928 to the mid-1950s quartz was produced in local quarries owned by the plant. 


\section{Exposure information}

During the second world war production was intensive and doors and windows were kept closed which may have lead to comparatively high exposure levels. No environmental surveys were carried out before 1975 when a comprehensive industrial hygiene monitoring programme was performed.5 These measurements showed that the concentration of total dust in the working areas near the ferrosilicon furnaces ranged from 0.8 to $5 \mathrm{mg} / \mathrm{m}^{3}$ at the tapping floor, from 3 to $10 \mathrm{mg} / \mathrm{m}^{3}$ during tapping, and from 6 to $26 \mathrm{mg} / \mathrm{m}^{3}$ during charging, whereas maintenance workers operated in an atmosphere containing between 4 and $46 \mathrm{mg} / \mathrm{m}^{3}$ of mixed dust. The ferrochromium furnace operators worked in an atmosphere with from 0.3 to $24 \mathrm{mg} / \mathrm{m}^{3}$ general dust and from 0.04 to $0.29 \mathrm{mg} / \mathrm{m}^{3}$ total chromium. The highest concentration was during packing when the concentrations of mixed dust sometimes exceeded $25 \mathrm{mg} /$ $\mathrm{m}^{3}$. It was on the tapping floor that workers spent a great proportion of their active working time. At the charge floor the mean concentration of total chromium was $0.05 \mathrm{mg} / \mathrm{m}^{3}$, of which $11-33 \%$ was water soluble. The water soluble chromium compounds are considered to be in the hexavalent state.

Asbestos has been used in the furnaces for heat insulation. During the years of production there has been no obvious difference in the use of asbestos at the ferrosilicon and the ferrochromium furnaces. In general, the workers employed by the plant have maintained the furnaces.

\section{Material and methods \\ STUDY POPULATION}

The area in which the study plant is located used to be isolated, at least until the $1940 \mathrm{~s}$. Traditionally, the local population was occupied with fruit production and dairy farming. The study plant is the only major employer in the area. Therefore, most of the workers have been recruited from the local population, which has resulted in a stable workforce. During the second world war, however, workers were recruited from elsewhere. Several workers were continuously employed from the late 1920s and early 1930s until they retired in the 1970s.

The number of full time workers increased gradually from 50 in 1928 to about 250 in 1932 and 450 in 1940 . Since the war the number has varied between 400 and 500 . After 1976-7 the number of full time workers has gradually been reduced to about 300 in 1988.

\section{METHODS}

The present investigation was designed as a cohort study of incidence of cancer and total mortality. The study population was generated from workers employed for more than one year at the plant from 1928 onwards. To allow for an assumed development time for cancer of 20 years or longer, those employed for the first time after 1 January 1965 were excluded from the study cohort. As the Cancer Registry of Norway gives a complete coverage of the whole Norwegian population since 1 January 1953, the 25 workers who had died before that date were excluded. As the total number of female workers was small before 1965 women were also excluded.

The figures for observed and expected cases of cancer were generated from the data in the Cancer Registry, which contains all cases of cancer and their locations that have occurred in the whole female and male Norwegian population from 1 January 1953 to date, except for epithelial skin cancer. The observation period for incidence of cancer is from 1 January 1953 to 31 December 1985. The expected number of deaths was based on age specific national death rates by five year age groups for each calendar year from 1953 to 1985 . To make comparison with previous results possible, a separate presentation was performed on incidence of cancer and deaths to the end of 1985 in the cohort of 976 members employed for the first time before 1960, which was reported on previously. ${ }^{5}$ This subset of the population was otherwise restricted according to the criteria presented above and was included in the whole cohort.

The cohort was generated on the basis of a complete personnel list containing all workers employed by the company from 1928 . Workers from the 1930 s with names beginning with the two last letters of the alphabet were lost due to water leakage in the storage place. This deficiency, however, was not considered to constitute selection in the recruitment cohort. Information on surrogates for personal exposure for each individual member of the cohort was collected from three different sources; $(a)$ the personnel lists provided by the company included job categories for about $40 \%$ of the cohort members; (b) detailed work history for those workers employed between 1946 and 1952 as recorded by the companies industrial physician; and (c) supplementary information from 10 independent, old workers, some of whom had been employed from the early 1930s. All information on job categories and exposure was collected in 1975-6.

The job categories listed on the basis of the first two sources were not told to the 10 workers and the information provided by them was checked against that from the other two sources. Those job categories and work periods which were confirmed by the first or the second interview were accepted. In cases of discrepancies, the information given from the interview with the closest work relation to the subject was accepted. These interviews were performed in 1975 by one of the authors (SL).

The present follow up is based on the same job descriptions and exposure category that served as basis assignment to job categories in the first follow 
up of the population. ${ }^{5}$ Three workers classified as electrode producers in that paper were classified under "various jobs" in the present study.

It is of interest to know to what extent the workers have moved from one job to another during employment in the plant. The individual work histories showed that change of job between the job categories has been limited for those workers who have been employed at the plant for a long period. Work at the ferrosilicon and ferrochromium furnaces has been quite specialised. Therefore, among the workers assigned to these two job categories less than $10 \%$ had changed from one category to another. When workers had served at both types of furnaces, that category where the worker had served the longest period was chosen as job category. The electrical shop and electric power station workers (category 7) were also skilled workers. Hence, this small group of workers has been quite stable and may be considered as belonging specifically to that exposure category.

Ninety five per cent confidence intervals $(\mathrm{CI})$ are presented on the basis of an assumed Poisson distribution of the cases of cancer.

\section{Results}

Table 1 shows the results from the follow up of the same subset of the population that was included in the previous study5: the crude death rates, the incidence of cancer at all sites, stomach cancer, bronchial cancer, and cancer of the prostate during the whole observation period. The table also shows (in parentheses) the corresponding figures for the extended observation from 1978 to 1985 . The total number of observed cases of cancer has risen from 64 $(\mathrm{E}=79.4)$ to $124(\mathrm{E}=144.9)$.

The observed number of stomach cancers had increased by three, whereas the expected figures had increased from 11.5 to 16.4 . The total number of cancers of the lungs and bronchial tree has increased from nine to 17 , whereas the corresponding expected figures have risen from $9 \cdot 5$ to $19 \cdot 4$. A deficit of lung cancer was observed in the ferrosilicon group; two cases observed versus 5.75 expected; the deficit for other sites was less apparent. There was an excess of lung cancer in the ferrochromium group; 10 versus 6.5 expected $(\mathrm{CI}=4.8,18.4)$, a slight reduction of the rate ratio in the previous study. Three cases of lung cancer had occurred in this subgroup during the extended observation period versus 3.05 expected. An excess of cancer of the prostate was still present; 31 observed versus 26.6 expected, which is less than in the previous observation period. ${ }^{5}$

The following results are derived from the whole study population. Table 2 shows the total observed number of deaths and cases of cancer that had occurred in the study population by the end of 1985 . As may be calculated from this table, the standardised mortality ratio (SMR) for all deaths is 81 , whereas the standardised incidence ratio (SIR) is 84 for all cancers. The SMR was below unity in all job categories and as low as 44 among white collar workers (category 6). A minor difference is seen between the SMRs in the ferrosilicon group $(S M R=75)$ and the ferrochromium group (SMR $=88)$. The SIRs for all cancers in these two groups were 69 and 116, respectively. The figures in parentheses shows that 30 cases of cancer versus $22 \cdot 8$

Table 1 Observed $(O)$ and expected $(E)$ cases of cancer, all sites, stomach cancer (151), lung and bronchial cancer (162), and cancer of the prostate (177) in the subpopulation first employed before 1 January 1960. Observation period is from January 1953 to December 1985. (Observed and expected figures for the extended observation period (1978-85) are given in parentheses)

\begin{tabular}{|c|c|c|c|c|c|c|c|c|c|c|c|c|}
\hline \multirow[b]{2}{*}{ Job category } & \multirow{2}{*}{$\begin{array}{l}\text { No of } \\
\text { workers }\end{array}$} & \multicolumn{2}{|c|}{ All deaths } & \multicolumn{2}{|c|}{ All cancers } & \multicolumn{2}{|c|}{$\begin{array}{l}\text { Stomach } \\
\text { cancer }\end{array}$} & \multicolumn{2}{|c|}{$\begin{array}{l}\text { Bronchial } \\
\text { cancer }\end{array}$} & \multicolumn{2}{|c|}{$\begin{array}{l}\text { Cancer of } \\
\text { prostate }\end{array}$} & \multirow{2}{*}{$\begin{array}{l}\text { Person- } \\
\text { years } \\
1953-85\end{array}$} \\
\hline & & $O$ & $E$ & $O$ & $E$ & $O$ & $E$ & $O$ & $E$ & $O$ & $E$ & \\
\hline Various jobs (1) & 83 & 29 & 31.55 & 8 & $11 \cdot 11$ & 0 & $1 \cdot 23$ & 1 & $1 \cdot 28$ & 1 & $\begin{array}{l}1.96 \\
0.92)\end{array}$ & $2312 \cdot 5$ \\
\hline Ferrosilicon (2) & 243 & $\begin{array}{r}88 \\
(30\end{array}$ & $\begin{array}{c}121 \cdot 30 \\
49 \cdot 34)\end{array}$ & $\begin{array}{r}30 \\
(15\end{array}$ & $\begin{array}{l}42 \cdot 99 \\
18 \cdot 16)\end{array}$ & $\begin{array}{r}3 \\
6\end{array}$ & $\begin{array}{l}0.34) \\
5.00 \\
1.43)\end{array}$ & $\begin{array}{r}2 \\
2 \\
(2\end{array}$ & $\begin{array}{l}5 \cdot 08 \\
2 \cdot 29)\end{array}$ & $\begin{array}{r}4 \\
(2\end{array}$ & $\begin{array}{l}8 \cdot 92) \\
8 \cdot 53 \\
4 \cdot 19)\end{array}$ & 6812 \\
\hline Ferrochromium (3) & 325 & $\begin{array}{l}107 \\
(51\end{array}$ & $\begin{array}{c}123 \cdot 33 \\
55 \cdot 26)\end{array}$ & $\begin{array}{r}54 \\
(29\end{array}$ & $\begin{array}{l}45 \cdot 75 \\
21 \cdot 32)\end{array}$ & $\begin{array}{r}7 \\
(2\end{array}$ & $\begin{array}{l}4 \cdot 83 \\
1 \cdot 61)\end{array}$ & $\begin{array}{l}10 \\
(3\end{array}$ & $\begin{array}{l}6 \cdot 14 \\
3 \cdot 05)\end{array}$ & $\begin{array}{l}12 \\
(7\end{array}$ & $\begin{array}{l}7 \cdot 68 \\
4 \cdot 35)\end{array}$ & $9450 \cdot 5$ \\
\hline Internal maintenance & 88 & $\begin{array}{r}19 \\
6\end{array}$ & $\begin{array}{l}26 \cdot 18 \\
10 \cdot 17 \text { ) }\end{array}$ & $\begin{array}{r}5 \\
(2\end{array}$ & $\begin{array}{l}9 \cdot 10 \\
4 \cdot 12)\end{array}$ & $\begin{array}{r}0 \\
0\end{array}$ & $\begin{array}{l}0.86 \\
0.30)\end{array}$ & 1 & $\begin{array}{l}1.20 \\
0.63)\end{array}$ & $\begin{array}{r}2 \\
(0\end{array}$ & $\begin{array}{l}1 \cdot 34 \\
0 \cdot 68)\end{array}$ & $2569 \cdot 5$ \\
\hline Quartz quarry (5) & 45 & $\begin{array}{l}19 \\
(7\end{array}$ & $\begin{array}{r}19 \cdot 15 \\
6 \cdot 87)\end{array}$ & $\begin{array}{r}4 \\
(1\end{array}$ & $\begin{array}{l}6 \cdot 30 \\
2 \cdot 24)\end{array}$ & $\begin{array}{r}0 \\
0\end{array}$ & $\begin{array}{l}0.76 \\
0.17)\end{array}$ & $\begin{array}{r}0 \\
0\end{array}$ & $\begin{array}{l}0.73 \\
0.31)\end{array}$ & $\begin{array}{r}2 \\
(0\end{array}$ & $\begin{array}{l}1 \cdot 16 \\
0 \cdot 44)\end{array}$ & 1237.5 \\
\hline Office workers (6) & 41 & $\begin{array}{r}7 \\
(4\end{array}$ & $\begin{array}{c}17 \cdot 24 \\
7 \cdot 83)\end{array}$ & $\begin{array}{r}3 \\
(1\end{array}$ & $\begin{array}{l}6 \cdot 63 \\
3 \cdot 15)\end{array}$ & $\begin{array}{r}0 \\
(0\end{array}$ & $\begin{array}{l}0.74 \\
0.25)\end{array}$ & $\begin{array}{r}0 \\
(0\end{array}$ & $\begin{array}{l}0.75 \\
0.40)\end{array}$ & $\begin{array}{r}2 \\
(1\end{array}$ & $\begin{array}{l}1 \cdot 18 \\
0.57)\end{array}$ & $1248 \cdot 5$ \\
\hline Electric shops (7) & 49 & $\begin{array}{l}17 \\
(7\end{array}$ & $\begin{array}{r}21 \cdot 30 \\
8 \cdot 06)\end{array}$ & $\begin{array}{r}8 \\
(2\end{array}$ & $\begin{array}{l}7 \cdot 41 \\
2 \cdot 69 \text { ) }\end{array}$ & $\begin{array}{r}0 \\
(0\end{array}$ & $\begin{array}{l}0.92 \\
0.21)\end{array}$ & $\begin{array}{r}0 \\
(0\end{array}$ & $\begin{array}{l}0.75 \\
0.31)\end{array}$ & $\begin{array}{r}4 \\
(1\end{array}$ & $\begin{array}{l}1.51 \\
0.59)\end{array}$ & $1400 \cdot 5$ \\
\hline External maintenance & 39 & 13 & $\begin{array}{c}18.07 \\
5.62)\end{array}$ & $\begin{array}{r}3 \\
1\end{array}$ & $\begin{array}{l}6 \cdot 56 \\
2 \cdot 22)\end{array}$ & 1 & $\begin{array}{l}0 \cdot 83 \\
0 \cdot 17)\end{array}$ & $\begin{array}{r}0 \\
(0\end{array}$ & $\begin{array}{l}0.72 \\
0.31)\end{array}$ & $\begin{array}{r}2 \\
(0\end{array}$ & $\begin{array}{l}1 \cdot 40 \\
0.45)\end{array}$ & $1088 \cdot 5$ \\
\hline Internal transport (9) & 63 & $\begin{array}{l}31 \\
(8\end{array}$ & $\begin{array}{r}31 \cdot 80 \\
9 \cdot 76)\end{array}$ & $\begin{array}{r}9 \\
(3\end{array}$ & $\begin{array}{l}9 \cdot 42 \\
3 \cdot 65)\end{array}$ & $\begin{array}{r}2 \\
(0\end{array}$ & $\begin{array}{l}1.16 \\
0.29)\end{array}$ & $\begin{array}{r}3 \\
(2\end{array}$ & $\begin{array}{l}1 \cdot 12 \\
0.45)\end{array}$ & $\begin{array}{r}2 \\
(1\end{array}$ & $\begin{array}{l}1 \cdot 82 \\
0 \cdot 85)\end{array}$ & $1584 \cdot 5$ \\
\hline Total & 976 & $\begin{array}{r}330 \\
(126\end{array}$ & $\begin{array}{l}409 \cdot 94 \\
165 \cdot 30)\end{array}$ & $\begin{array}{l}124 \\
(57\end{array}$ & $\begin{array}{r}144.96 \\
62.07)\end{array}$ & $\begin{array}{l}13 \\
(3\end{array}$ & $\begin{array}{c}16 \cdot 43 \\
4 \cdot 76)\end{array}$ & $\begin{array}{l}17 \\
(8\end{array}$ & $\begin{array}{c}17 \cdot 76 \\
8 \cdot 33)\end{array}$ & $\begin{array}{r}31 \\
(12\end{array}$ & $\begin{array}{l}26 \cdot 59 \\
13 \cdot 13)\end{array}$ & 27704 \\
\hline
\end{tabular}


Table 2 Observed $(O)$ and expected $(E)$ deaths and cases of cancer. Observation time from 1 January 1953 to 31 December 1985. Workers first employed after 1 January 1965 were excluded. (Observed and expected number of cases of deaths and cancer for the extended observation period (1978-85) are given in parentheses)

\begin{tabular}{|c|c|c|c|c|c|c|}
\hline \multirow[b]{2}{*}{ Job category } & \multirow{2}{*}{$\begin{array}{l}\text { No of } \\
\text { workers }\end{array}$} & \multicolumn{2}{|l|}{ All deaths } & \multicolumn{2}{|c|}{ All cancers } & \multirow{2}{*}{$\begin{array}{l}\text { Person- } \\
\text { years } \\
1953-85\end{array}$} \\
\hline & & $O$ & $E$ & $O$ & $E$ & \\
\hline $\begin{array}{l}\text { Various jobs } \\
\text { Ferrosilicon } \\
\text { Ferrochromium } \\
\text { Internal maintenance } \\
\text { Quartz quarry } \\
\text { Office workers } \\
\text { Electrical shops } \\
\text { External maintenance } \\
\text { Internal transport }\end{array}$ & $\begin{array}{r}117 \\
320 \\
379 \\
114 \\
46 \\
53 \\
58 \\
49 \\
99\end{array}$ & $\begin{array}{rr}34 & 13) \\
100 & (34) \\
114 & (54) \\
20 & (6) \\
19 & (7) \\
8 & (4) \\
17 & (7) \\
13 & (2) \\
36 & (10)\end{array}$ & $\begin{array}{rr}36 \cdot 23 & (14 \cdot 78) \\
132.91 & (55 \cdot 34) \\
129 \cdot 26 & (58 \cdot 43) \\
27.60 & (10 \cdot 90) \\
19 \cdot 01 & (6 \cdot 89) \\
18 \cdot 12 & (8 \cdot 29) \\
21 \cdot 79 & (8 \cdot 34) \\
19.03 & (6 \cdot 17) \\
36.41 & (12.37)\end{array}$ & $\begin{aligned} & 8(3) \\
& 33(17) \\
& 56(30) \\
& 5(2) \\
& 4(1) \\
& 3(1) \\
& 8(2) \\
& 3(1) \\
& 12(5)\end{aligned}$ & $\begin{aligned} 12.52 & (5.48) \\
47.70 & (20.81) \\
48.25 & (22.83) \\
9.69 & (4.49) \\
6.32 & (2.25) \\
7.01 & (3.38) \\
7.62 & (2.82) \\
7.00 & (2.51) \\
12.25 & (4.70)\end{aligned}$ & $\begin{array}{r}3000 \cdot 0 \\
8349 \cdot 0 \\
10561 \cdot 0 \\
3072 \cdot 0 \\
1262 \cdot 5 \\
1509 \cdot 0 \\
1592 \cdot 5 \\
1294 \cdot 5 \\
2285 \cdot 0\end{array}$ \\
\hline Total & 1235 & 357 (137) & $440.56(181.51)$ & $132(62)$ & $157 \cdot 34(69 \cdot 26)$ & 32925.5 \\
\hline
\end{tabular}

expected had occurred in the ferrochromium group during the extended observation period. Except for the ferrochromium group, all job categories show deficits in the incidence of cancers at all sites.

Table 2 also shows that the number of workers and number of person-years is lower in the ferrosilicon group than in the ferrochromium group, whereas the expected number of deaths and cases of cancer is virtually the same in the two subgroups. This difference between number of person-years and expected cases of cancer and deaths indicates that the ferrosilicon group consists of slightly older workers than the ferrochromium group.

Table 3 gives the job specific observed and expected number of cases of cancer at all sites and a selected set of tumour sites in the whole study population at the end of 1985 . The observed figures are lower than the expected for most job categories; SIRs may be calculated from the figures. For lung cancer the SIR for ferrosilicon workers was only 35 , whereas the incidence was still in excess in the ferrochromium workers (SIR $=154$ ). Three cases of lung cancer versus 3.26 expected had occurred in the ferrochromium group during the extended follow up.
There was still a slight excess of cancer of the prostate in the whole population; 32 cases observed versus 28.2 expected. A deficit was still seen in the ferrosilicon group but an excess $(S I R=151)$ was noted in the ferrochromium group. Nevertheless, the excess has decreased during the extended observation period; seven cases occurred versus 4.57 expected (numbers not shown in table 3).

The workers in the ferrochromium and the ferrosilicon groups have performed the same type of work and dust exposure in the two groups has also been similar, except for exposure to chromium: compounds. Therefore, internal comparison between the groups would have been interesting. The two groups, however, have not been internally standardised for age, and may therefore not be used as each others reference groups. As the mean age among the ferrosilicon group is slightly higher than that of the ferrochromium group, comparing the ferrochromium group with the other group leads to minor underestimation of the rate ratios. For lung cancer such a comparison gives $R R=4.3$; for cancer of the prostate, the $R R$ is $\mathbf{2 \cdot 8}$.

As shown in table 3, malignant tumours of the

Table 3 Observed $(O)$ and expected $(E)$ deaths, cases of cancer all sites, and cases at selected cancer sites occurring in the study population during the observation period from 1 January 1953 to 31 December 1985

\begin{tabular}{|c|c|c|c|c|c|c|c|c|}
\hline \multirow[b]{3}{*}{ Deaths and cancer sites } & \multicolumn{8}{|c|}{ Selected work categories } \\
\hline & \multicolumn{2}{|c|}{ All categories } & \multicolumn{2}{|c|}{ Ferrosilicon } & \multicolumn{2}{|c|}{ Ferrochromium } & \multicolumn{2}{|c|}{ Electrical shops } \\
\hline & $O$ & $E$ & $O$ & $\boldsymbol{E}$ & $O$ & $E$ & $O$ & $E$ \\
\hline $\begin{array}{l}\text { All deaths } \\
\text { All cancer sites } \\
\text { Cancer of the }\end{array}$ & $\begin{array}{l}361 \\
132\end{array}$ & $\begin{array}{l}423 \cdot 1 \\
157 \cdot 3\end{array}$ & $\begin{array}{c}114 \\
33^{\star}\end{array}$ & $\begin{array}{r}125 \cdot 1 \\
47 \cdot 7\end{array}$ & $\begin{array}{r}100 \\
56\end{array}$ & $\begin{array}{r}125 \cdot 1 \\
48 \cdot 3\end{array}$ & $\begin{array}{r}17 \\
8\end{array}$ & $\begin{array}{r}19 \cdot 9 \\
7 \cdot 6\end{array}$ \\
\hline $\begin{array}{l}\text { Stomach }(151) \\
\text { Rectum }(154) \\
\text { Pancreas }(157) \\
\text { Bronchi }(162 / 163) \\
\text { Prostate (177) } \\
\text { Kidney (180) } \\
\text { Malignant melanomas (190) }\end{array}$ & $\begin{array}{r}14 \\
10 \\
7 \\
17 \\
32 \\
9 \\
6\end{array}$ & $\begin{array}{r}17 \cdot 4 \\
8 \cdot 1 \\
6 \cdot 2 \\
19 \cdot 4 \\
28 \cdot 2 \\
5 \cdot 6 \\
3 \cdot 9\end{array}$ & $\begin{array}{l}4 \\
6 \\
2 \\
2 \\
5 \\
2 \\
1\end{array}$ & $\begin{array}{l}5 \cdot 4 \\
2 \cdot 5 \\
1 \cdot 9 \\
5 \cdot 8 \\
9 \cdot 2 \\
1 \cdot 7 \\
0 \cdot 3\end{array}$ & $\begin{array}{r}7 \\
2 \\
3 \\
10 \\
12 \\
5 \\
0\end{array}$ & $\begin{array}{l}5 \cdot 0 \\
2 \cdot 5 \\
1 \cdot 9 \\
6 \cdot 5 \\
8 \cdot 0 \\
1 \cdot 8 \\
0 \cdot 4\end{array}$ & $\begin{array}{l}0 \\
0 \\
0 \\
0 \\
4 \\
1 \\
2 \star\end{array}$ & $\begin{array}{l}0.9 \\
0.4 \\
0 \cdot 3 \\
0 \cdot 8 \\
1 \cdot 5 \\
0 \cdot 3 \\
0 \cdot 2\end{array}$ \\
\hline Person-years 1953-85 & 926 & & 8349 & & 10561 & & 1592 & \\
\hline
\end{tabular}

*Significant at $95 \%$ level 
Table 4 Year of birth, time of first employment, work category, duration of employment in years, and year of diagnosis for the nine cases of renal cancer observed in the study cohort

\begin{tabular}{|c|c|c|c|c|c|}
\hline Born & $\begin{array}{l}\text { Year of } \\
\text { diagnosis }\end{array}$ & $\begin{array}{l}\text { Age when } \\
\text { cancer } \\
\text { diagnosed }\end{array}$ & $\begin{array}{l}\text { Time of } \\
\text { first } \\
\text { employment }\end{array}$ & $\begin{array}{l}\text { Department } \\
\text { of work }\end{array}$ & $\begin{array}{l}\text { Duration } \\
\text { of } \\
\text { employment }(y)\end{array}$ \\
\hline
\end{tabular}

kidneys and malignant melanomas of the skin are in excess. The over all excess of renal tumours appears to be explained by the excess in the ferrochromium workers (table 4), where five cases were observed versus 1.83 expected $(\mathrm{CI}=1.6,11 \cdot 7)$. In the municipality where the plant is located there were seven cases versus 5.0 expected, based on national figures, from 1975 to $1984 .{ }^{10}$ It could be confirmed that at least six of these seven cases were recruited from the study population. Table 4 also shows that five of the subjects with renal cancer were first employed during the 1940s. It may be calculated from table 4 that the mean time between first employment and occurrence of renal cancer is 37.3 years for all cases, and 39 years for the five cases occurring in the ferrochromium group. Malignant melanomas (ICD 190) are in excess in the whole population (table 3); over all, SIR $=156$. Two cases versus $0 \cdot 19$ expected in the power station and electrical shops workers account for most of this difference.

\section{Discussion}

The present study was carried out in a population that was characterised for exposure surrogates in 1975-6, and categorisation was carried out without knowledge of illnesses or deaths. There is no way that assignment to subgroups of cases of cancer and deaths occurring after 1975-6 could be influenced by the allocation of the workers to the different categories. Exclusion of 26 subjects who died before 1 January 1953 might have lead to a slight "healthy" survivor effect among the remaining members of the cohort. Considering the long observation period in this study, however, the assumed dilution of the results as a result of this exclusion must be small.

The results from the present study show that the excess incidence of lung cancer in the ferrochromium subpopulation has been reduced to some extent during the eight year extended observation period. The SIR for the employees from before 1960 was 163 (table 1) versus 151 for the whole ferrochromium subpopulation (table 3 ). Table 1 shows that all 10 cases of lung cancer in the ferrochromium group occurred in the subgroup first employed before 1960 , and that no additional cases occurred among ferrochromium workers first employed between 1960 and 1965 (table 3). Nevertheless, the observation period for the subgroup employed between 1960 and 1965 is only 20 to 25 years, which may be too short for the development of exposure related lung cancer at levels of chromium ${ }^{\mathrm{IV}}$ as low as in the present study. Another possible explanation for the observed reduction could be that the levels of exposure to the causal agents have been reduced since the late 1950s. In the present small study, however, the observed reduction should not be considered to be robust and may be due to chance.

The incidence of lung cancer among male residents of the municipality where the plant is located was lower than for the country as a whole $($ SIR $=59)$ during $1976-85 .^{10}$ This local population basis was considered too small to be used for reference purposes. If the local male population were to be used as reference population, however, the SIR for lung cancer in the ferrochromium groups would be 256 .

In addition to water soluble (presumably hexavalent) chromium compounds in the working atmosphere the workers have also been exposed to high concentrations of fumes and dust particles with unspecified composition. Long term exposure to unspecified dust and fumes in the working atmosphere has been indicated as being accompanied by a risk of cancer. ${ }^{11}$ Such unspecified dust and fumes are considered to be present to about the same extent at the ferrosilicon and ferrochromium worksites. Therefore, it seems unlikely that this exposure could affect the two groups differently. Both subgroups may have been exposed to low concentrations of polycyclic aromatic hydrocarbons and intermittent low level exposure to crysotile asbestos particles. It may be assumed, however, that exposure to these factors has been similar in both subgroups.

Information on smoking habits among the workers was not available. There is no obvious reason why work at the ferrochromium furnaces should be more attractive to smokers than work at the ferrosilicon furnaces. In fact, smoking during work close to any of the furnaces has always been prohibited, which to 
some extent may have discouraged smokers from this type of employment.

On the other hand, exposure to low levels of chromium compounds has occurred only among the ferrochromium group. Therefore, at present no other exposure factor than low levels of compounds containing chromium ${ }^{\mathrm{IV}}$ can be pointed out as an explanation for the difference between the incidence rates of lung cancer in the two subgroups.

An excess in renal cancer has also been observed among workers in other Norwegian ferroalloy smelteries, ${ }^{12}$ which makes the excess in the ferrochromium group in the present study noteworthy. The overall excess in the present study $(\operatorname{SIR}=159)$ was at the same level as in a recently published study in a calcium carbide producing population. ${ }^{12}$ In a population of workers producing ferrosilicon and ferrovanadium the excess of renal cancer was even higher $(\mathrm{O} / \mathrm{E}=4 / 0.9)$ (J Alexander, XX International Congress on Occupational Health, Cairo, 25 September-1 October, 1981:476 (abstract)). At present, little can be said about the possible aetiology of these observed excesses of renal cancer.

In this study the excess was observed in the ferrochromium subgroup only, which might indicate that possible causal exposure factor(s) could be associated with work at ferrochromium furnaces. The results do not explain the possible relation between work related exposure and the occurrence of renal cancers. It seems worth noticing that the mean "latency time" for these cases was as long as $37 \cdot 3$ years in the whole group and 39 years for the five cases occurring in the ferrochromium group (table 4). A relation with work at the ferrochromium furnaces would probably have resulted in a reduced latency time compared with the other cases. Therefore, if the excess incidence of renal cancer is related to work exposure it is more likely to be related to aspects of the work other than exposure to chromium.

The observed over all excess of malignant melanoma may be a spurious result. As malignant melanomas have become increasingly focused in relation to work related exposure, ${ }^{13-15}$ the two cases in the electrical shops and power station workers may add to the list of occupations that should be considered as being of interest in relation to occurrence of malignant melanomas.

As in the previous study ${ }^{5}$ the overall incidence of cancer of the prostate was increased $(S I R=110)$. When including those who had been first employed between 1960 and 1964 (table 3), the overall SIR in the ferrochromium group was reduced to 151 . In the municipality in which the plant is located 43 cases occurred versus 36.9 expected based on national figures during the period $1975-84 .^{10}$

1 Lehmann KB. Ist Grund zu einer besonderen Beunruhigung wegen des Auftretens von Lungenkrebs bei Chromatarbeit vorhanden? Zentralblatt für Gewerbehygiene 1932;19:168-70.

2 Machle W, Gregorius F. Cancer in the respiratory system in the United States chromate-producing industry. Public Health Rep 1948;63:1114-27.

3 International Agency for Research on Cancer. Monographs on the evaluation of the carcinogenic risk of chemicals to humans. Some metals and metallic compounds. Vol 23. Chromium and chromium compounds. Lyon: IARC, 1980.

4 Pokrovskaja LV, Shabynina NK. Carcinogenous hazard in the production of chromium ferroalloys. Gig $\mathrm{Tr}$ Prof Zabol 1975;10:23-6.

5 Langård $S$, Andersen A, Gylseth B. Incidence of cancer among ferrochromium and ferrosilicon workers. $\mathrm{Br} \mathrm{J}$ Ind $\mathrm{Med}$ 1980;37:114-20.

6 Axelsson G, Rylander R, Schmidt A. Mortality and tumour incidence among ferrochromium workers. $\mathrm{Br} J$ Ind Med 1980;37:121-7.

7 United States Environmental Protection Agency. Health assessment document for chromium. Research Triangle Park, North Carolina, 1984.

8 World Health Organisation. International programme on chemical safety. Environmental health criteria 61; chromium. Geneva: WHO, 1988.

9 World Health Organisation. Regional Office for Europe. Air quality guidelines for Europe. Geneva: WHO, 1987:221-32. (WHO regional publications, European series No 23.)

10 Cancer Registry of Norway. Occurrence of cancer in Norwegian municipalities; new cases 1975-1984. Oslo: Kreftregisteret, 1986. (In Norwegian.)

11 Kjuus $\mathrm{H}$, Lislerud A, Lyngdal PT, Omland $\mathrm{H}$, Stave $\mathrm{O}$ Langard S. Cancer and polluted work places: a case-control study. Int Arch Environ Health 1982;49:281-92.

$12 \mathrm{Kjuus} \mathrm{H}$, Andersen $\mathrm{A}$, Langård $\mathrm{S}$. Incidence of cancer among workers producing calcium carbide. $\mathrm{Br} J$ Ind Med 1986;43: 237-42.

13 Storetvedi Heldaas S, Andersen A, Langard S. Incidence of cancer among vinyl chloride and polyvinyl chloride workers an extended follow up study. Br J Ind Med 1987;44:278-80.

14 Storetvedt Heldaas S, Langärd S, Andersen A. Incidence of cancer among vinyl chloride and polyvinyl chloride workers. Br J Ind Med 1984;41:25-30.

15 O'Berg MT, Burke CA, Chen JL, Walrath J, Pell S, Gallie CR. Cancer incidence and mortality in the Du Pont Company: an update. J Occup Med 1987;29:245-51.

Accepted 13 March 1989 